\title{
Directional Hydraulic Fracturing Application for Reduction of Rock Heaving Intensity in the Development Opening under Conditions of S.M. Kirov Mine
}

\author{
Vladimir Klishin \\ Siberian Branch of the Institute of Coal \\ Russian Academy of Sciences \\ Kemerovo, Russian Federation \\ klishinvi@icc.kemsc.ru
}

\author{
Gleb Opruk \\ Siberian Branch of the Institute of Coal \\ Russian Academy of Sciences \\ Kemerovo, Russian Federation \\ opruk@yandex.ru
}

\author{
Alexander Ponizov \\ S.M. Kirov Mine \\ JSC "SUEK-Kuzbass" \\ Leninsk-Kuznetsky, Russian Federation \\ office@suek.ru
}

\begin{abstract}
The article reveals the application experience of directional hydraulic fracturing to reduce rock heaving intensity in the development opening of the following longwall face. The authors developed a scheme of roof weakening at longwall exit from the installation chamber. It also helps prevent rock heaving in conveyer roadway 2593 . The mechanism of rock heaving was studied. The authors determined the scheme of mine pressure distribution and rock heaving in the conveyer roadway at coal extraction in the longwall face. The authors measured the rock heaving values along the working considering the held activities. The authors made conclusions and gave respective recommendations.
\end{abstract}

Keywords - directional hydraulic fracturing, rock heaving, high rock pressure zone, coal pillar, difficult caving roof

\section{INTRODUCTION}

At present when the mining depth is increasing, the mining face is progressing faster, mining, geological and technical conditions are getting more complicated, and the issue of rock heaving control in workings is becoming more urgent for specialists working in many coal mines in Russia. There are different rock heaving mechanisms and various ways of dealing with them. For example, pressure unloading on the working edge by means of fractures and boreholes, drainage and electrochemical hardening, softening by explosion and bedrock hardening, bolting, etc. But in fact, heaved rock cutting is the only measure really practiced in mines. [1,2,3]

\section{EXPERIMENTAL RESEARCH METHODS}

Borehole blasting method has proved to be efficient because it helps reduce pressure on edges of barrier pillars and prevent soil heaving [4,5]. In order to use this method there should be a blasting explosives user license. Besides, the scope of drilling long boreholes with diameter up to 100 $\mathrm{mm}$ in the tough rock is sufficient. It also implies using considerable volume of explosives, taking people out of the mine when there are blasting works, ventilation of workings, etc. That complicates extensive application of the method.
But directional hydraulic fracturing method does not have these disadvantages [6,7]. That became one of the reasons for using the method to control rock heaving under conditions of mine named after S.M. Kirov.

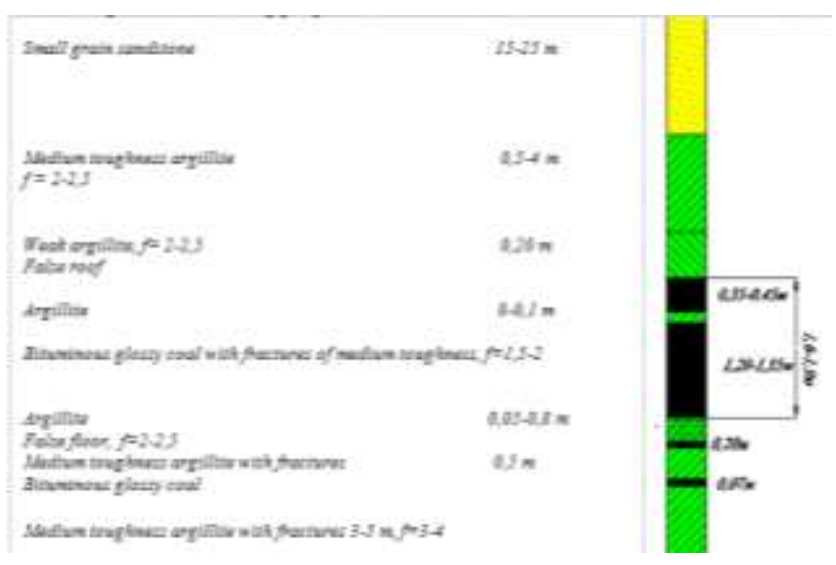

Fig. 1. Stratigraphic column of Polenovsky coal bed.

Airway 2591 was made along the coal bed Polenovsky 300-420 m under the earth surface. The stratigraphic column is given in Fig. 1. There can be parts with thinner immediate roof and parts where main roof is represented by sandstone ( $\mathrm{f}=6-7$ ) up to $26 \mathrm{~m}$ thick just over the coal bed. Bedrock consists of coal and medium-strength fractured argillite interbedding. The width of barrier pillars between the long faces is $20 \mathrm{~m}$ (Fig. 2).

225-415 m under the earth surface just over Polenovsky coal bed there is Boldyrevsky coal bed 2,15-2,50 m thick. It has been fully mined and the barrier pillars between the longwalls were left. Projections of these pillars along Boldyrevsky coal bed are made almost directly on the barrier pillars left along Polenovsky coal bed (Fig. 2. Original rock pressure zones). When block 2591 was mined the barrier pillar between the longwalls near the airway was just under the pillar left over it in the coal bed Boldyrevsky (Fig. 2). According to mine engineering service inspection when the longwall face moved from the installation chamber $200 \mathrm{~m}$ 
away there was bedrock heaving ahead it in the adjacent conveyer roadway of the next longwall 2592 being prepared.

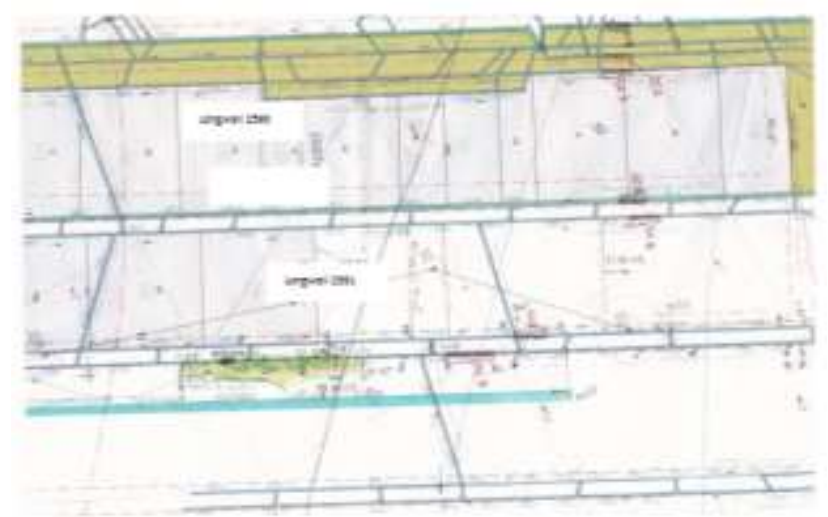

Fig. 2. Fragment of the mining works plan along the coal bed Polenovsky in mine named after S.M. Kirov.

When the longwall face approached the break-down chamber and the distance was $350 \mathrm{~m}$ the rock heaving took place $90 \mathrm{~m}$ behind powered roof support. The intensity of heaving was sufficiently lower. In general, in the central part of the longwall within 500-700 m there was rock heaving in the conveyer roadway of the new prepared longwall face 2592 with maximum heaving in its central part and formation of deep fractures that spread radially from the source (Fig. 3).

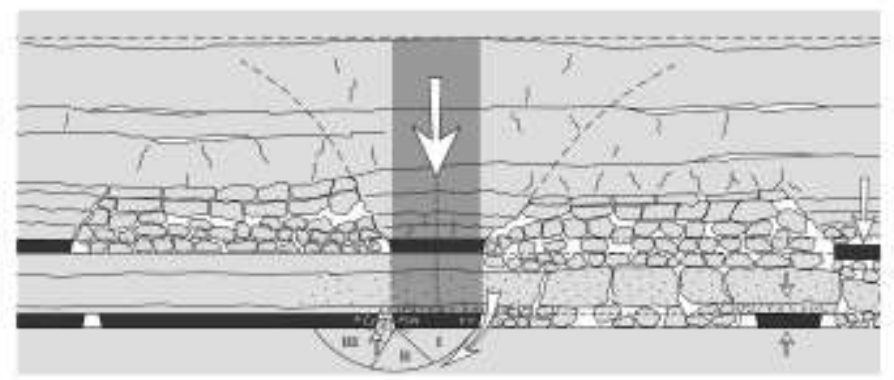

Fig. 3. The scheme of pressure distribution and rock heaving in the conveyer roadway at longwall mining.

Mechanism of heaving involves brittle crashing of extremely strained coal and wall rock into pieces of different shape (I II III (Fig. 3)), their penetration into underlying bed rock, their layer-by-layer shift with formation of folds and debris heaps (formation and heaping of hummocks), displacement of the broken rock into the gob [1]. Under conditions of the mine named after S.M. Kirov the combination of the active forces mentioned above when coal was tough appeared as displacement of rock in the barrier pillar. Loss of stability took place not as plastic flow, but as breaking at bending due to the following reasons:

1. load transfer from mining pressure to the barrier pillars, placed one under another. That lead to horizontal stress accumulation in these parts causing rock heaving (bed rock was softened due to the presence of natural fractures) and its surface failure;

2. thickness of the immediate roof was about $1,5 \mathrm{~m}$ on the given part of the mine field. When the thickness of the extracted seam was equal to $1,72 \mathrm{~m}$ the rock of the main roof was not supported by crashed rock;

3. bed rock displacement from the area under the barrier pillar was due to the extra pressure caused by caving of up to $26 \mathrm{~m}$ thick ( $\mathrm{f}=6-7)$ sandstone layers into the gob. This leads to rock pillar bending and complex load increase on the pillar that initiates its "turn" (Fig. 3). That process causes accumulation of horizontal stress in the bed rock and its displacement.

This situation in the working face of the development opening 2592 required dismounting of partially installed conveyer later and passing the conveyor roadway again. That caused additional expenses. But bed rock cleaning and removing of bulging rock layer can cause even more intensive heaving. Further it was evident when longwall 2592 was mined. This leads to conveyer removing to ventilation airway.

Taking into consideration that the barrier pillar (between the longwalls) of the following development opening 2593 will be under the same conditions concerning pressure on the first stage, the authors made a decision to make hydraulic fractures from the ventilation airway of longwall face 2592 . The intensity of rock heaving can be reduced by means of bedrock relief from high horizontal stress using induced directional fractures. As a result, the peaks of stress accumulation are shifted from the parts most vulnerable to destruction deep into the rock mass. That ensures energy transfer from the active forces in the given direction, in other words redistribution of active forces direction (Fig. 4) [3].

a)

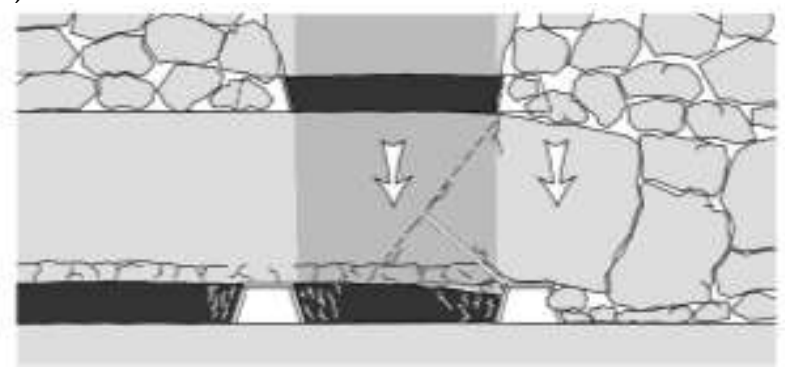

b)

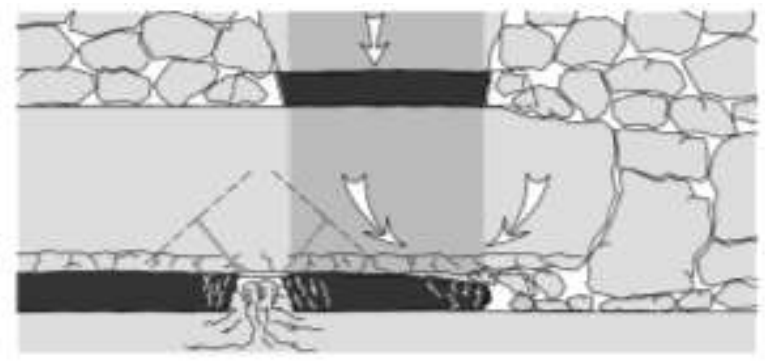

Fig. 4. Scheme of directional hydraulic fracturing implementation on the main roof from the airway of the mined longwall to preserve conveyer roadway against heaving of the following development opening: a - works are performed from the prepared longwall face located next to it;

$\mathrm{b}$ - works are performed from the longwall face located next to it.

There was preliminary experimental testing of initial main roof caving in longwall 2592. It revealed high effectiveness of the suggested method and schemes of directional fractures distribution (Fig. 5,6). The scheme of boreholes location in the installation chamber to reduce the magnitude of initial main roof caving is implemented in two variants: with fracture initiation on one or two levels. The works are taken out of the installation chamber before extraction works).

Technical plan and parameters of boreholes location to implement directional hydraulic fracturing are chosen in 
each case according to the assigned task depending on the mining, geological and technical conditions in the area which should be softened. To soften the roof for initial caving two-level scheme of vertical boreholes location was used to decompose rock mass of the first $(1,3,5,7)$ and second $(2,4,6,8)$ levels. The boreholes were 4 and $6 \mathrm{~m}$ deep (Fig. 5). To get the most sufficient effect at the preliminary rock softening according to the project the scheme "cutting caving" should be used to obtain initiated fractures in the rock mass which have to be across rock layers. For that reason the authors suggested to make slanted boreholes in the installation chamber $(1,9)$. They should be slanted in the direction of working face advance. The boreholes for "cutting caving" are made between vertical boreholes (Fig. 5). Besides, boreholes (10-14) for "cut caving" are made from the development openings at an angle to the bedding. This helps remove roof caving on the pillars between the longwalls $[7,8,9]$.

Vertical boreholes guarantee rock layering and slanted boreholes help cut off the roof and prevent its caving over the coal mass. The combination of these technological activities gives the biggest effect at preliminary roof rock softening for timely initial roof caving. Preparation of directional horizontal fractures for hydraulic fracturing together with cutting ones, slanted in the direction of development openings advance, makes it possible to obtain man-made block of rock which destroys on time behind the powered roof support. According to experiments and visual inspection, the scheme of roof caving when powered mining complex is taken out of the installation chamber can be presented in the following way (Fig. 6). [10,11]

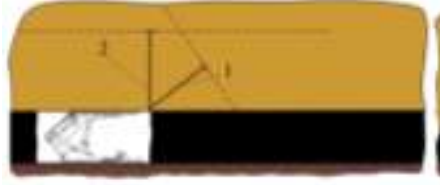

Before support exit from the installation chamber

Fig. 5. Mechanism of tough roof softening by means of decomposition and its cutting using directional hydraulic fracturing from the installation chamber.

During testing depending on the particular conditions and obtained results, the scheme and parameters of boreholes placement are adjusted $[12,13,14]$.

Directional hydraulic fracturing according to the scheme (Fig 5,6) was used in the airway of longwall 2592 to cut the block of the main roof. That helped to redistribute sufficient part of load from the pillar to the caved rock. To control the processes taking part in the conveyer roadway of the following longwall 2593 measuring stations \#1 and \#2 were placed in it 100 meters away from the installation chamber in which there were measuring points located 10 meters away from each other (each station was $100 \mathrm{~m}$ long, and there were measuring points inside the station). In other words, $200 \mathrm{~m}$ of the opening were controlled (Fig. 7).

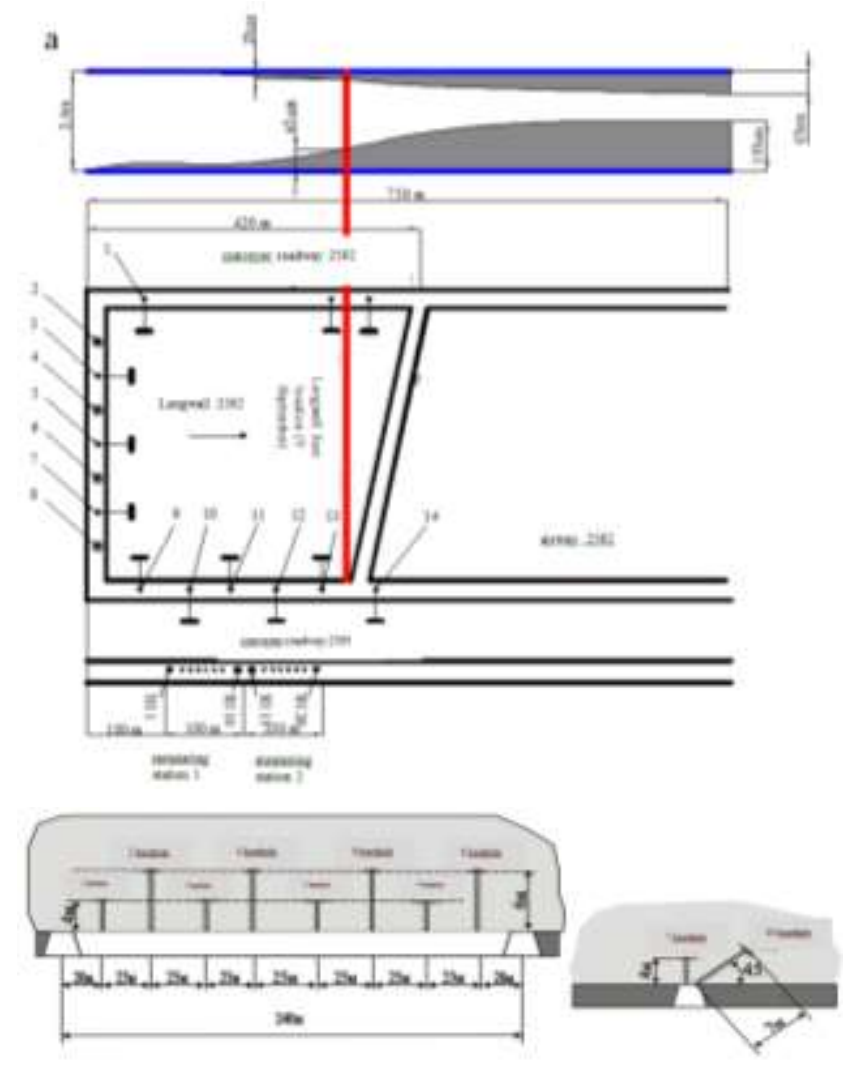

Fig. 6. Scheme of boreholes placement for further directional hydraulic fracturing for the primary roof caving and taking preventive measures against rock heaving in conveyer roadway 2593: 1-9 - boreholes for primary main roof caving; 9-14 - cutting boreholes.

\section{RESULTS AND DISCUSSIONS}

Initial caving took place when the longwall was $25 \mathrm{~m}$ away from the break-down chamber. This did not cause rock heaving. At the same time roof caving reached $50 \mathrm{~m}$ in longwall 2591 located above. Rock began to heave just after longwall advance. Later hydraulic fractures were made by means of the cutting boreholes, bored in the direction of longwall and pillar out of the bearing pressure zone (Fig. 6). The results of the mean measurement values from 10 measuring points on stations 1 and 2 (Fig. 8) at development opening approaching them and further increase of distance to them show high efficiency of the performed works. When development opening advances 350-370 $\mathrm{m}$ from installation chamber maximum rock heaving value in conveyer roadway of longwall 2593 was just $61 \mathrm{~mm}$ (Fig. 7). At the same time when longwall 2591 was mined, rock heaving in conveyer roadway of longwall 2592 at the same distance reached 650 $\mathrm{mm}$. This shows that rock heaving was reduced almost 10 times.

On the site where the support of roof rock was not cut bed rock displacement of the airway 2593 has increased up to $1,35 \mathrm{~m}$, roof rock displacement reached $650 \mathrm{~mm}$. Because of that one more working was made, namely, airway 2593bis. 


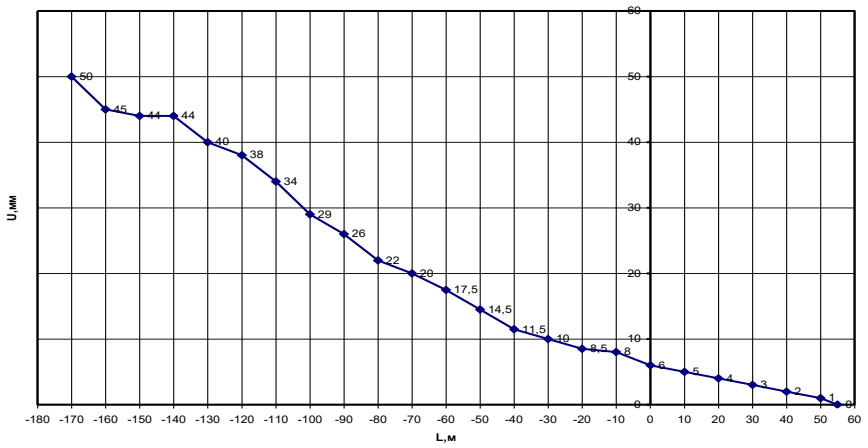

a)

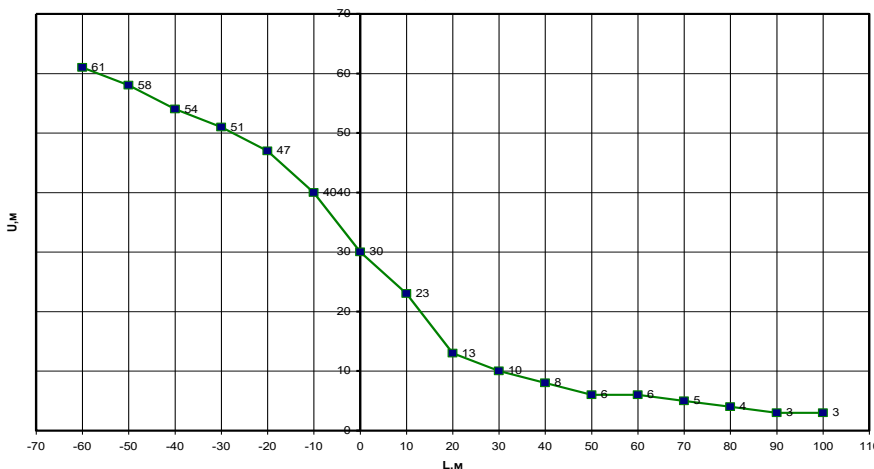

b)

Fig. 7. Dependence of rock heaving value (U) on the distance to longwall \# 2592 (L) in conveyer roadway\# 2593 (mean value of 10 measurement points results): a) data from measuring point \# 1; b) data from measuring point \# 2.

\section{CONCLUSIONS}

1. The block of the main roof $15-25 \mathrm{~m}$ thick that did not find reliable support on the heaved rock in the gob compared to original rock pressure created much bigger load on the pillar between the longwalls. This caused lateral load on bed rock.

2. The scheme of the directional hydraulic fracturing used under conditions of mine named after S.M. Kirov proved to be very efficient for initial main roof caving. It helped prevent the caving of the roof block on the pillar between the longwalls and its support by the crashed rock.

3. On the part of the working, where the authors used directional hydraulic fracturing for "cutting caving" from the other side of the pillar between the longwalls, the intensity of bedrock heaving reduced sufficiently.

4. Directional hydraulic fracturing can be recommended as an effective method that helps control bed rock heaving. But its parameters and presumed effect are calculated in each particular case considering mining, geological and technical conditions

\section{ACKNOWLEDGEMENT}

The research was carried out funded by Russian Scientific Fund grant (Project \#17-17-01143).

\section{REFERENCES}

[1] Oganesian S.A. Accident in JSC "Juzhkuzbassugol" affiliate "Taizhina Mine". Chronicle, causes, conclusions // Ugol, 2004, \#6, pp. 25-28.

[2] Tsivka Ju.V., Petrov A. N. Hydrodynamic notions in Barentsburg ore mine on Spitsbergen archipelago // Ugol, 2005, \#7, pp. 49-50.

[3] Lekontsev, Yu.M., Sazhin, P.V. Application of the directional hydraulic fracturing at Berezovskaya Mine. 2008. Journal of Mining Science, 44 (3), pp. 253-258.

[4] Klishin, V.I., Opruk, G.Y., Tatsienko, A.L. Technology and means of a coal seam interval hydraulic fracturing for the seam degassing Intensification (2017) IOP Conf. Ser. Earth and Env. Sci, 53 (1), 012019

[5] Chernov O.I., Ku N.G. Rock fluid fracturing // FTPRPI (Physical and technical issues of fossil fuels extraction). - 1988. - \#6, pp. 81-92.

[6] Dzhevetsky Ja. New methods of dangerous rock bumps prevention. Glukauf, 2002, \#2 (3).

[7] Klishin VI, Opruk GYu, Vessel AO 2016 Science intensive technologies in mineral resources extraction and usage No 3 pp. 27-33.

[8] Chernov O.I. Hydrodynamic stratification of solid rock as a means of tough roof control // FTPRPI (Physical and technical issues of fossil fuels extraction). - 1982. \#2. pp. 18-22.

[9] Klishin, V.I., Fokin, Yu.S., Lekontsev, Yu.M. Working the powerful high gasbearing coal beds in the conditions of hardly destructing roof (2005) Gornyi Zhurnal, (12), pp. 112-114.

[10] Lekontsev, Y.M., Patutin, A.V., Sazhin, P.V., Temiryaeva, O.A. Hybrid unit for directional hydrofracturing. 2016. Journal of Mining Science, 52 (3), pp. 511-515.

[11] Sikora, W, A. Kidybinski, and K. Saltysek. Designing of Hard RoofRock Destressing Systems for Safe Warning of Rock Burst Prone Coal Seams, Central Mining Institute Report, Poland, 1978.

[12]. Lekontsev, Yu.M., Sazhin, P.V., Ushakov, S.Yu. Interval hydraulic fracturing to weaken dirt bands in coal. 2012. Journal of Mining Science, 48 (3), pp. 525-532

[13] S. Cherny , D. Esipov, Dm. Kuranakov, V. Lapin, D. Chirkov, A. Astrakova. Prediction of fracture initiation zones on the surface of threedimensional structure using the surface curvature. Engineering Fracture Mechanics 172. 2017. pp. 196-214.

[14] Lekontsev, Yu.M., Sazhin, P.V., Temiryaeva, O.A., Khoreshok, A.A., Ushakov, S.Yu. Two-side sealer operation. 2013. Journal of Mining Science, 49 (5), pp. 757-762. 